\title{
Introduction to the special issue
}

I am grateful to Professor Peter K.W. Fong, the Editor-in-Chief, for inviting me to be the Guest Editor for this special issue of Public Administration and Policy on "Corruption scandals in six Asian countries." Corruption is a serious problem in many Asian countries as, according to Transparency International's Corruption Perceptions Index (CPI) in 2019, 19 (70 per cent) of the 27 Asian countries surveyed have scores below 50, ranging from 16 for Afghanistan to 41 for China and India.

As no country is immune from corruption scandals, the aim of this Public Administration and Policy special issue is to contribute to the literature on corruption scandals in Asian countries. It consists of seven articles: a comparative article and six articles on selected corruption scandals in India, Japan, Macau, Malaysia, the Philippines and Singapore. The first article by Jon Quah provides a comparative overview and analysis of the selected corruption scandals in the six Asian countries. The second article on constitutional corruption in India is written by Krishna Tummala. The third article by Matthew Carlson analyses two sontaku-linked scandals in Japan. In the fourth article, Sonny Lo focuses on the corruption scandals of two principal officials in Macau, Ao Man-long and Ho Chio-meng. The fifth article by David Seth Jones provides an in-depth analysis of the infamous 1MDB scandal in Malaysia. The sixth article, which is written by Eric Batalla, deals with two grand corruption scandals involving the procurement of two infrastructure projects in the Philippines. The final article by Jon Quah compares the Teh Cheang Wan and Edwin Yeo corruption scandals in Singapore.

I would like to thank all the contributors to this Public Administration and Policy special issue for their fine contributions and cooperation in revising and submitting their manuscripts promptly. All the contributors and I owe a huge debt of gratitude to the 14 peer-reviewers for their constructive feedback which has enhanced the quality of the seven articles. Last but not least, I am also grateful to Prof Peter Fong, Editor, Dr Alice Te, and Associate Editor, Dr Franky Choi, for their cooperation and assistance in facilitating the publication of this special issue of Public Administration and Policy.

Jon S.T. Quah

Special Issue Guest Editor, PAP Journal Anti-Corruption Consultant, Singapore

(C) Jon S.T. Quah. Published in Public Administration and Policy. Published by Emerald Publishing Limited. This article is published under the Creative Commons Attribution (CC BY 4.0) licence. Anyone may reproduce, distribute, translate and create derivative works of this article (for both commercial and non-commercial purposes), subject to full attribution to the original publication and authors. The full terms of this licence may be seen at http://creativecommons.org/licences/by/4.0/legalcode

HKPAA

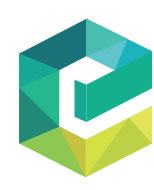

Public Administration and Policy Vol. 23 No. 1,2020 Emerald Publishing Limited DOI 10.1108/PAP-06-2020-037 